\title{
METAZOAN PARASITES OF BRAZILIAN MENHADEN \\ Brevoortia aurea (SPIX \& AGASSIZ, 1829) (OSTEICHTHYES: CLUPEIDAE) FROM THE COASTAL ZONE OF THE STATE OF RIO DE JANEIRO, BRAZIL
}

\author{
TAVARES, L. E. R., LUQUE, J. L. and BICUDO, A. J. A. \\ Curso de Pós-graduação em Ciências Veterinárias, Departamento de Parasitologia Animal, Universidade Federal \\ Rural do Rio de Janeiro, C.P. 74508, CEP 23851-970, Seropédica, RJ, Brazil \\ Correspondence to: José Luis Luque, Departamento de Parasitologia Animal, Universidade Federal Rural do Rio de \\ Janeiro, C.P. 74508, CEP 23851-970, Seropédica, RJ, Brazil, e-mail: jlluque@ufrrj.br \\ Received December 16, 2002 - Accepted April 17, 2003 - Distributed August 31, 2004
}

Brazilian menhaden Brevoortia aurea (Spix \& Agassiz, 1829) is a nerito-pelagic fish occurring in coastal zones and in marine, brackish, and estuarine habitats, with known geographic distributions in the southwestern Atlantic Ocean, from Rio de Janeiro to the Argentine (Figueiredo \& Menezes, 1978). A planktivorous species, it usually presents schooling habits with high populational density of specimens. Brevoortia aurea is very important as bait for commercial fishery and is used on a large scale for oil and flour production (Carvalho-Filho, 1999).

The monogenean Mazocraeoides georgei Price, 1936, was reported as parasitic on B. aurea from Guanabara Bay, Rio de Janeiro, Brazil (Kohn \& Santos, 1988; Kohn \& Cohen, 1998). However, no further studies have been reported on the parasites of this fish up to the present date.

Between January and February 2001, fortytwo specimens of Brazilian menhaden measuring $29.56 \pm 2.39(27-38 \mathrm{~cm})$ in total length, were examined from Jacarepaguá Lagoon, Rio de Janeiro, RJ, Brazil (2259'S, 4323’ W).

After identification (Figueiredo \& Menezes, 1978), the fishes were necropsied to study their metazoan parasite infracommunities, and all organs, body cavities, and body surface were examined. The monogeneans collected were fixed in $10 \%$ formalin, stored in ethanol $70^{\circ} \mathrm{GL}$, and stained in Gomori's trichromic. The nematodes were fixed in AFA, stored in ethanol $70^{\circ} \mathrm{GL}$, and cleared with lactophenol. The terms mean abundance, mean intensity, and prevalence of infection/infestation are according to Bush et al. (1997). The following analysis included only parasite species with prevalence higher than $10 \%$
(Bush et al., 1990). Dominance frequency and relative dominance (number of specimens of one species/total number of specimens of all species in the infracommunity) of each parasite species were calculated (Rohde et al., 1995). Spearman's rank correlation coefficient $r_{s}$ was calculated to determine possible correlations between the total length of hosts and parasite abundance. Pearson's correlation coefficient $r$ was used as an indication of the relationship between the host's total length and parasite prevalence, with previous arcsine transformation of prevalence data (Zar, 1999). The effect of host sex on abundance and parasite prevalence was tested using the $Z_{c}$ normal approximation to the Mann-Whitney test and the Fisher exact test, respectively. Voucher specimens of studied helminths were deposited in the Coleção Helmintológica do Instituto Oswaldo Cruz (CHIOC), Rio de Janeiro, Brazil.

Eighty-eight percent of $B$. aurea was parasitized by at least one metazoan species and a total of 683 metazoan parasite specimens was collected, with mean $16.3 \pm 43.6$ parasite/fish. Five metazoan parasite species were determined (Table 1). Mazocraeoides georgei Price, 1936, was the most abundant, prevalent, and dominant species, representing $93.4 \%$ of metazoan parasites collected with mean relative dominance $0.699 \pm 0.417$ and frequency of dominance $71.4 \%$. Host length was not correlated with parasite abundance and prevalence $\left(r_{s}=0.115, \mathrm{p}=0.467\right.$ and $r=0.89$, $\mathrm{p}=0.215)$. Host sex did not influence parasite abundance $\left(Z_{c}=-1.076, \mathrm{p}=0.278\right)$ but showed significant influence on parasite prevalence $(\mathrm{p}=0.026)$, parasitizing $94 \%$ of the males and $64 \%$ of the females. 
TABLE 1

Prevalence, mean intensity, mean abundance, and site of infection/infestation of the metazoan parasites of Brevoortia aurea from the coastal zone of the State of Rio de Janeiro, Brazil.

\begin{tabular}{|c|c|c|c|c|}
\hline Parasite & Prevalence \% & $\begin{array}{l}\text { Mean } \\
\text { intensity }\end{array}$ & $\begin{array}{c}\text { Mean } \\
\text { abundance }\end{array}$ & $\begin{array}{c}\text { Site of infection } \\
\text { infestation }\end{array}$ \\
\hline \multicolumn{5}{|l|}{ Monogenea } \\
\hline $\begin{array}{l}\text { Mazocraeoides georgei Price, } 1936 \\
\text { (CHIOC 34943a,b) }\end{array}$ & 76.2 & $19.9 \pm 49.1$ & $15.2 \pm 43.6$ & Gills \\
\hline \multicolumn{5}{|l|}{ Nematoda } \\
\hline $\begin{array}{l}\text { Anisakis sp. (larval) } \\
\text { (CHIOC 34688) }\end{array}$ & 9.5 & $1.8 \pm 1.0$ & $0.2 \pm 0.6$ & Mesenteries \\
\hline $\begin{array}{l}\text { Contracaecum sp. (larval) } \\
\text { (CHIOC 34689) }\end{array}$ & 9.5 & $4.5 \pm 3.0$ & $0.4 \pm 1.6$ & Mesenteries \\
\hline $\begin{array}{l}\text { Pseudoterranova sp. (larval) } \\
\text { (CHIOC 34694) }\end{array}$ & 9.5 & $2.0 \pm 2.0$ & $0.2 \pm 0.8$ & Mesenteries \\
\hline $\begin{array}{l}\text { Procamallanus } \mathrm{sp} . \\
\text { (CHIOC 34693) }\end{array}$ & 9.5 & $1.0 \pm 1.0$ & $0.1 \pm 0.3$ & Intestine \\
\hline
\end{tabular}

Menhadens are commonly parasitized by ectoparasites (Carvalho-Filho, 1999; Kohn \& Santos, 1988; Felley et al., 1987) and were considered debilitated if injured by ectoparasites, thus rendering them more susceptible to daytime surface trawling (Guthrie \& Kroger, 1974). The schooling habits exhibited by this host might explain the dominance of monoxenous parasites like M. georgei. However, studies on quantitative aspects of parasitism in clupeid fishes from the coastal zone of the State of Rio de Janeiro reported digenean dominance (Luque et al., 2000). Nevertheless, the occurrence of larvae and adult nematodes parasitic in Brazilian menhaden is reported for the first time. In agreement with Luque et al. (2000), our results confirmed that additional studies are needed to evaluate the structure of clupeid parasite communities in the neotropical region.

Acknowledgements - J. L. Luque was supported by a Research fellowship from CNPq (Conselho Nacional de Pesquisa e Desenvolvimento Tecnológico). L. E. Tavares and A. A. Bicudo were supported by student fellowships from CAPES (Coordenação de Aperfeiçoamento do Pessoal de Ensino Superior).

\section{REFERENCES}

BUSH, A. O., AHO, J. M. \& KENNEDY, C. R., 1990, Ecological versus phylogenetic determinants of helminth parasite community richness. Evol. Ecol., 4: 1-20.
BUSH, A. O., LAFFERTY, K. D., LOTZ, J. M. \& SHOSTAK, A. W., 1997, Parasitology meets ecology on its own terms: Margolis et al. revisited. J. Parasitol., 83: 575-83.

CARVAlHO-FILHO, A., 1999, Peixes: costa brasileira. Ed. Melro Ltda, São Paulo, 320p.

FELLEY, S. M., VECCHIONE, M. \& HARE, S. G. F., 1987, Incidence of ectoparasitic copepods on ichthyoplankton. Copeia, 3: 778-782.

FIGUEIREDO, J. L. \& MENEZES, N. A., 1978, Manual de peixes marinhos do Sudeste do Brasil. II. Teleostei (1). Museu de Zoologia, Universidade de São Paulo, SP, 110p.

GUTHRIE, J. F. \& KROGER, R. L., 1974, Schooling habits of injured and parasitized menhaden. Ecology, 55: 208-210.

KOHN, A. \& SANTOS, C. P., 1988, First report of Mazocraeoides georgei Price 1936 and Mazocraeoides opisthonema Hargis, 1955 in Brazil with new synonyms (Monogenea, Mazocraeoides). Mem. Inst. Oswaldo Cruz, 83: 437-440.

KOHN, A. \& COHEN, S. C., 1998, South American Monogenealist of species, hosts and geographical distribution. Int. Jour. Parasitol., 28: 1517-1554.

LUQUE, J. L., VIÑAS, R. A., PARAGUASSÚ, A. R. \& ALVES, D. R., 2000, Metazoários parasitos das sardinhas Sardinella brasiliensis e Harengula clupeola (Osteichthyes: Clupeidae) do litoral do estado do Rio de Janeiro, Brasil. Rev. Univ. Rural. Ciênc. Vida, 2: 71-76.

ROHDE, K., HAYWARD, C. \& HEAP, M., 1995, Aspects of the ecology of metazoan ectoparasites of marine fishes. Int. Jour. Parasitol., 25: 945-970.

ZAR, J. H., 1999, Biostatistical analysis. Prentice-Hall, New Jersey, 663p. 